\title{
Characterization of T-type calcium current and its contribution to electrical activity in rabbit urethra
}

J. E. Bradley, U. A. Anderson, S. M. Woolsey, K. D. Thornbury, N. G. McHale and M. A. Hollywood

Am J Physiol Cell Physiol 286:C1078-C1088, 2004. First published 3 December 2003;

doi:10.1152/ajpcell.00463.2003

You might find this additional info useful...

This article cites 29 articles, 17 of which can be accessed free at:

http://ajpcell.physiology.org/content/286/5/C1078.full.html\#ref-list-1

This article has been cited by 4 other HighWire hosted articles

Contribution of $K_{\mathrm{v}} 2.1$ channels to the delayed rectifier current in freshly dispersed smooth muscle cells from rabbit urethra

B. Kyle, E. Bradley, S. Ohya, G. P. Sergeant, N. G. McHale, K. D. Thornbury and M. A.

Hollywood

Am J Physiol Cell Physiol, November, 2011; 301 (5): C1186-C1200.

[Abstract] [Full Text] [PDF]

Calcium Signaling in Smooth Muscle

David C. Hill-Eubanks, Matthias E. Werner, Thomas J. Heppner and Mark T. Nelson

Cold Spring Harb Perspect Biol, September, 2011; 3 (9): .

[Abstract] [Full Text] [PDF]

Organization and function of ICC in the urinary tract

N. G. McHale, M. A. Hollywood, G. P. Sergeant, M. Shafei, K. T. Thornbury and S. M. Ward J Physiol, November 1, 2006; 576 (3): 689-694.

[Abstract] [Full Text] [PDF]

Spontaneous activity of lower urinary tract smooth muscles: correlation between ion channels and tissue function

A. F. Brading

J Physiol, January 1, 2006; 570 (1): 13-22.

[Abstract] [Full Text] [PDF]

Updated information and services including high resolution figures, can be found at:

http://ajpcell.physiology.org/content/286/5/C1078.full.html

Additional material and information about AJP - Cell Physiology can be found at: http://www.the-aps.org/publications/ajpcell

This infomation is current as of March 8, 2012.

AJP - Cell Physiology is dedicated to innovative approaches to the study of cell and molecular physiology. It is published 12 times a year (monthly) by the American Physiological Society, 9650 Rockville Pike, Bethesda MD 20814-3991. Copyright () 2004 by the American Physiological Society. ISSN: 0363-6143, ESSN: 1522-1563. Visit our website at http://www.the-aps.org/. 


\title{
Characterization of T-type calcium current and its contribution to electrical activity in rabbit urethra
}

\author{
J. E. Bradley, U. A. Anderson, S. M. Woolsey, K. D. Thornbury, N. G. McHale, and M. A. Hollywood \\ Smooth Muscle Group, Department of Physiology, The Queen's University of Belfast, Belfast, BT9 7BL, North Ireland
}

Submitted 23 October 2003; accepted in final form 28 November 2003

Bradley, J. E., U. A. Anderson, S. M. Woolsey, K. D. Thornbury, N. G. McHale, and M. A. Hollywood. Characterization of T-type calcium current and its contribution to electrical activity in rabbit urethra. Am J Physiol Cell Physiol 286: C1078-C1088, 2004. First published December 3, 2003; 10.1152/ajpcell.00463.2003.Rabbit urethral smooth muscle cells were studied at $37^{\circ} \mathrm{C}$ by using the amphotericin B perforated-patch configuration of the patch-clamp technique, using $\mathrm{Cs}^{+}$-rich pipette solutions. Two components of current, with electrophysiological and pharmacological properties typical of T- and L-type $\mathrm{Ca}^{2+}$ currents, were recorded. Fitting steadystate inactivation curves for the $\mathrm{L}$ current with a Boltzmann equation yielded a $V_{1 / 2}$ of $-41 \pm 3 \mathrm{mV}$. In contrast, the $\mathrm{T}$ current inactivated with a $V_{1 / 2}$ of $-76 \pm 2 \mathrm{mV}$. The $\mathrm{L}$ currents were reduced by nifedipine $\left(\mathrm{IC}_{50}=225 \pm 84 \mathrm{nM}\right), \mathrm{Ni}^{2+}\left(\mathrm{IC}_{50}=324 \pm 74 \mu \mathrm{M}\right)$, and mibefradil $\left(\mathrm{IC}_{50}=2.6 \pm 1.1 \mu \mathrm{M}\right)$ but were enhanced when external $\mathrm{Ca}^{2+}$ was substituted with $\mathrm{Ba}^{2+}$. The $\mathrm{T}$ current was little affected by nifedipine at concentrations $<300 \mathrm{nM}$ but was increased in amplitude when external $\mathrm{Ca}^{2+}$ was substituted with $\mathrm{Ba}^{2+}$. Both $\mathrm{Ni}^{2+}$ and mibefradil reduced the $\mathrm{T}$ current with an $\mathrm{IC}_{50}=7 \pm 1 \mu \mathrm{M}$ and $\sim 40$ $\mathrm{nM}$, respectively. Spontaneous electrical activity recorded with intracellular electrodes from strips of rabbit urethra consisted of complexes comprising a series of spikes superimposed on a slow spontaneous depolarization (SD). Inhibition of T current reduced the frequency of these SDs but had no effect on either the number of spikes per complex or the amplitude of the spikes. In contrast, application of nifedipine failed to significantly alter the frequency of the SD but reduced the number and amplitude of the spikes in each complex.

spontaneous activity; pacemaking; smooth muscle

URETHRAL MYOGENIC TONE has been demonstrated by a number of studies $(1,3,25)$ to be critically dependent on the influx of $\mathrm{Ca}^{2+}$ across the cell membrane, because inhibition of L-type $\mathrm{Ca}^{2+}$ channels or removal of external $\mathrm{Ca}^{2+}$ reduces tone significantly in rat, humans, and pig urethra in vitro. Recent evidence suggests that influx through $\mathrm{T}$-type $\mathrm{Ca}^{2+}$ channels may contribute to the maintenance of urinary continence given that application of $\mathrm{Ni}^{2+}$ can reduce urethral tone in the rat (25). A previous study from our laboratory (10) demonstrated the presence of two components of inward $\mathrm{Ca}^{2+}$ current in human proximal urethral myocytes that possessed electrophysiological properties typical of $\mathrm{T}$ and $\mathrm{L}$ channels observed in a variety of cell types (for reviews, see Refs. 15 and 22). Although the biopsy samples used by Hollywood et al. (10) were sufficient to allow the isolation of single cells, their small size precluded the detailed examination of the contribution of $\mathrm{T}$ currents to spontaneous electrical activity in the human urethra using intracellular microelectrodes.

Address for reprint requests and other correspondence: M. Hollywood, Smooth Muscle Group, Dept. of Physiology, The Queen's Univ. of Belfast, 97 Lisburn Road, Belfast, BT9 7BL, N. Ireland (E-mail: m.hollywood @qub.ac.uk; web site: www.smoothmusclegroup.org).
In this study, we first confirmed the presence of T-type $\mathrm{Ca}^{2+}$ currents in isolated rabbit urethral myocytes and characterized its electrophysiological and pharmacological properties. Having demonstrated that we could selectively block this current with appropriate concentrations of mibefradil or $\mathrm{Ni}^{2+}$, we assessed the contribution of $\mathrm{T}$ current to spontaneous electrical activity of the rabbit urethra using intracellular microelectrodes. Preliminary accounts of this work have been reported to the Physiological Society (2).

\section{MATERIALS AND METHODS}

Cell dispersal. Strips of tissue $0.5 \mathrm{~cm}$ in width were isolated from male and female New Zealand White rabbits, cut into $1-\mathrm{mm}^{3}$ pieces, and stored in $\mathrm{Ca}^{2+}$-free Hanks' solution (see Solutions) for $30 \mathrm{~min}$ before cell dispersal. Occasionally, the tissue was stored overnight in $\mathrm{Ca}^{2+}$-free Hanks' at $4^{\circ} \mathrm{C}$ before cell dispersal. Tissue pieces were incubated in dispersal medium containing (per $5 \mathrm{ml}$ of $\mathrm{Ca}^{2+}$-free Hanks' solution) $15 \mathrm{mg}$ of collagenase (type 1A, Sigma), $1 \mathrm{mg}$ of protease (type XXIV, Sigma), $10 \mathrm{mg}$ of bovine serum albumin (Sigma), and $10 \mathrm{mg}$ of trypsin inhibitor (Sigma) for 10-15 min at $37^{\circ} \mathrm{C}$. Tissue was then transferred to $\mathrm{Ca}^{2+}$-free Hanks' solution and stirred for a further 15-30 min to release single smooth muscle cells. These cells were plated in petri dishes containing $100 \mu \mathrm{M} \mathrm{Ca}^{2+}$ Hanks' solution and stored at $4^{\circ} \mathrm{C}$ for use within $8 \mathrm{~h}$.

Perforated-patch recordings from single cells. Currents were recorded by using the perforated-patch configuration of the whole cell patch-clamp technique (11). This circumvented the problem of current rundown encountered when the conventional whole cell configuration is used. The cell membrane was perforated by using the antibiotic amphotericin B $(600 \mu \mathrm{g} / \mathrm{ml})$. Patch pipettes were initially frontfilled by being dipped into pipette solution and then backfilled with the amphotericin B-containing solution. Pipettes were pulled from borosilicate glass capillary tubing (1.5-mm outer diameter, 1.17-mm inner diameter; Clark Medical Instruments) to a tip of diameter $\sim 1-1.5 \mu \mathrm{m}$ and a resistance of 2-4 M $\Omega$.

Voltage-clamp commands were delivered via an Axopatch 1D patch-clamp amplifier (Axon Instruments), and membrane currents were recorded with the use of a 12-bit analog-to-digital/digital-toanalog converter (Axodata 1200 or Labmaster-Scientific Solutions) interfaced to an Intel computer running pCLAMP software. During experiments, the dish containing the cells was continuously perfused with Hanks' solution at $36 \pm 1{ }^{\circ} \mathrm{C}$. Additionally, the cell under study was continuously superfused by means of a custom-built close delivery system with a pipette of tip diameter $200 \mu \mathrm{m}$ placed $\sim 300 \mu \mathrm{m}$ from the cell. The Hanks' solution in the close delivery system could be switched to a drug-containing solution with a dead space time of $<5$ s. In all experiments $n$ refers to the number of cells studied and each experimental set usually contained samples from a minimum of four animals. Summary data are presented as means $\pm \mathrm{SE}$, and statistical comparisons were made on raw data using Students' paired $t$-test, taking $P<0.05$ as significant.

The costs of publication of this article were defrayed in part by the payment of page charges. The article must therefore be hereby marked "advertisement" in accordance with 18 U.S.C. Section 1734 solely to indicate this fact. 
Intracellular recording. The bladder and urethra were removed from both male and female rabbits immediately after they had been killed by lethal injection of pentobarbitone. The most proximal $3 \mathrm{~cm}$ of the urethra were removed and placed in Krebs solution. This was then opened up, the urothelium was removed, and the preparation was pinned out on a silicon rubber base and superfused with Krebs solution at $35-37^{\circ} \mathrm{C}$. To prevent spontaneous contractions from dislodging impalements, we incubated tissues with $5 \mu \mathrm{M}$ wortmannin. Smooth muscle cells were impaled with glass microelectrodes filled with $3 \mathrm{M} \mathrm{KCl}$ and had a resistance of 80-120 M $\Omega$. Transmembrane potentials were recorded with a standard electrometer (IE 251; Warner Instruments) and stored on a personal computer running Stratchclyde Electrophysiology Software (WinEDR vers. 2.3.3). Drugs were superfused through the bath and left for at least $10 \mathrm{~min}$ before washout.

Solutions. The composition of the solutions used was as follows (in mM): 1) Hanks' solution: $129.8 \mathrm{Na}^{+}, 5.8 \mathrm{~K}^{+}, 135 \mathrm{Cl}^{-}, 4.17 \mathrm{HCO}_{3}^{-}$, $0.34 \mathrm{HPO}_{4}^{2-}, 0.44 \mathrm{H}_{2} \mathrm{PO}_{4}^{-}, 1.8 \mathrm{Ca}^{2+}, 0.9 \mathrm{Mg}^{2+}, 0.4 \mathrm{SO}_{4}^{2-}, 10$ glucose, 2.9 sucrose, and 10 HEPES, pH adjusted to 7.4 with $\mathrm{NaOH}$; 2) $\mathrm{Cs}^{+}$perforated-patch pipette solution: $133 \mathrm{Cs}^{+}, 135 \mathrm{Cl}^{-}, 1.0$ $\mathrm{Mg}^{2+}, 0.5$ EGTA, and $10 \mathrm{HEPES}, \mathrm{pH}$ adjusted to 7.2 with $\mathrm{CsOH} ; 3$ ) $\mathrm{Ba}^{2+}$ substituted Hanks' solution: $129.4 \mathrm{Na}^{+}, 5.4 \mathrm{~K}^{+}, 135 \mathrm{Cl}^{-}, 4.17$ $\mathrm{HCO}_{3}^{-}, 1.8 \mathrm{Ba}^{2+}, 0.9 \mathrm{Mg}^{2+}, 10$ glucose, 2.9 sucrose, and $10 \mathrm{HEPES}$, $\mathrm{pH}$ adjusted to 7.4 with $\mathrm{NaOH}$; and 4) Krebs solution: $146.2 \mathrm{Na}^{+}, 5.9$ $\mathrm{K}^{+}, 133.3 \mathrm{Cl}^{-}, 25 \mathrm{HCO}_{3}^{-}, 1.2 \mathrm{H}_{2} \mathrm{PO}_{4}^{-}, 2.5 \mathrm{Ca}^{2+}, 1.2 \mathrm{Mg}^{2+}$, and 11 glucose, $\mathrm{pH}$ maintained at 7.4 by bubbling with $95 \% \mathrm{O}_{2}-5 \% \mathrm{CO}_{2}$.

Drugs used. The following drugs were used: Amphotericin B (Sigma), $\mathrm{NiCl}_{2}$ (Sigma), nifedipine (Tocris), mibefradil (a gift from Roche), and wortmannin (Sigma). Stock solutions of $\mathrm{NiCl}_{2}(0.1 \mathrm{M})$ were made up in $\mathrm{H}_{2} \mathrm{O}$. Mibefradil and nifedipine $(1 \mathrm{mM})$ were made up in ethanol. All drugs were then diluted to their final concentrations in Hanks' solution. Drug vehicles had no effect on the currents studied.

\section{RESULTS}

With the use of our dispersal procedure, both interstitial cells and smooth muscle cells could be reliably isolated from the rabbit urethra as described previously (24). In the present study, we focused on studying the smooth muscle cells, which were unbranched, spindle shaped, and contracted in response to either depolarizing pulses or application of norepinephrine (10 $\mu \mathrm{M})$ but did not show spontaneous electrical activity. Under recording conditions identical to those used in previous studies (21), $>70 \%$ of rabbit urethral myocytes possessed both low voltage-activated (LVA) and high-voltage-activated (HVA) $\mathrm{Ca}^{2+}$ currents but rarely possessed $\mathrm{Ca}^{2+}$-activated $\mathrm{Cl}^{-}$currents $(<5 \%)$. On the basis of the electrophysiological and pharmacological data presented below, we henceforth refer to the HVA current as L current and the LVA current as T current. Interestingly, when cells were maintained at room temperature $\left(\sim 22^{\circ} \mathrm{C}\right)$, only L currents were apparent (data not shown). For this reason all experiments were carried out at $35-37^{\circ} \mathrm{C}$. We observed considerable variation in the amplitude of $\mathrm{T}$ current among cells. In 34 cells, a depolarizing step from
A
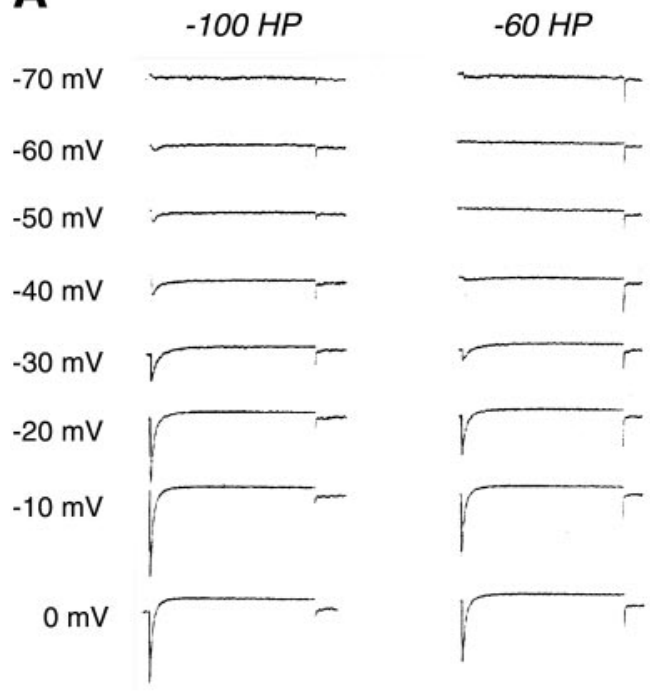

\section{Difference}

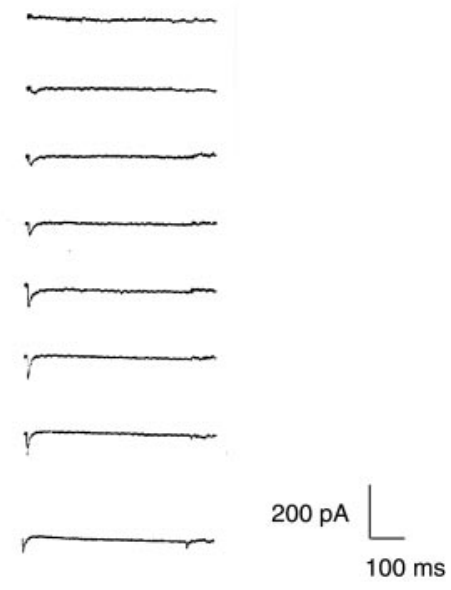

B

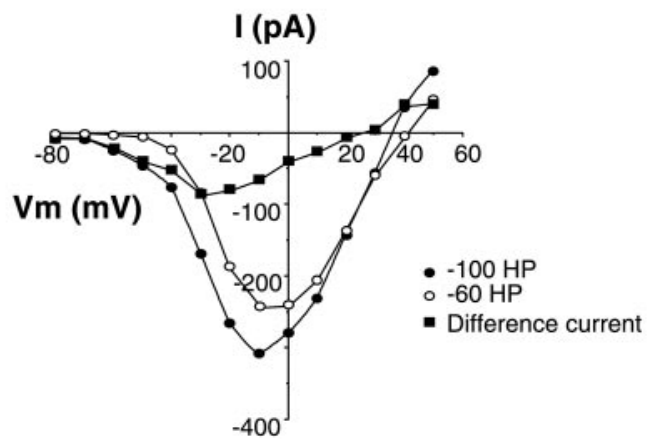

Fig. 1. Characteristics of $\mathrm{T}$ and $\mathrm{L}$ currents in human urethral smooth muscle cells. $A$ : families of currents recorded from a cell at holding potentials (HP) of -100 and $-60 \mathrm{mV}$. Currents at right are difference currents obtained by subtraction and demonstrate a negatively activating inward current that peaks at $-30 \mathrm{mV}$. B: a current-voltage $\left(I-V_{\mathrm{m}}\right)$ plot taken from the same cell in which the peak inward currents were plotted when cells were depolarized from holding potentials of -100 and $-60 \mathrm{mV}$. Difference currents were obtained by subtraction. 
-100 to $-40 \mathrm{mV}$ evoked a current that had a peak amplitude of $-57 \pm 6 \mathrm{pA}$ (range: -10 to $-149 \mathrm{pA}$ ).

Effect of altering holding potential on currents. Figure $1 A$ shows representative traces taken from an experiment in which a cell was held at potentials of either $-100 \mathrm{mV}$ (left) or -60 $\mathrm{mV}$ (middle) and then depolarized from $-70 \mathrm{mV}$ through to 0 $\mathrm{mV}$ for $500 \mathrm{~ms}$ in $10-\mathrm{mV}$ steps. When cells were held at -100 $\mathrm{mV}$ and then depolarized, inward currents activated at approximately $-60 \mathrm{mV}$. In contrast, when the same cell was held at $-60 \mathrm{mV}$ and the voltage steps repeated, inward currents activated at $-40 \mathrm{mV}$. To isolate the currents unmasked by holding the cell at $-100 \mathrm{mV}$, we obtained difference currents by subtracting the currents obtained at holding potentials of $-60 \mathrm{mV}$ from those at $-100 \mathrm{mV}$ (Fig. 1A, right). These difference currents activated at $\sim-60 \mathrm{mV}$, were maximal at $-30 \mathrm{mV}$, and reversed at $\sim 20 \mathrm{mV}$. Figure $1 B$ shows a current-voltage $(I-V)$ plot for the current obtained from this cell at holding potentials of -100 and $-60 \mathrm{mV}$ as well as the associated difference currents. A clear "shoulder" was apparent at negative potentials on the $I-V$ curve when the cell was held at $-100 \mathrm{mV}$. In contrast, when the cell was held at $-60 \mathrm{mV}$, the shoulder was absent. Subtraction of these two currents unmasked an inward current that activated at $-60 \mathrm{mV}$, peaked at $-30 \mathrm{mV}$, and reversed at $\sim 20 \mathrm{mV}$.
To compare the steady-state activation of both components of current, we constructed activation curves from currents evoked from cells held at $-60 \mathrm{mV}$ and difference currents obtained by subtraction, as described above. Figure 2, $B$ and $D$, shows summary data points, obtained from the $I-V$ relationships in seven cells, that were used to construct steady-state activation curves for $\mathrm{L}$ and $\mathrm{T}$ current, respectively. When these data were fitted with a Boltzmann equation of the form

$$
I / I_{\max }=1 /\left\{1+\exp \left[-K\left(V-V_{1 / 2}\right)\right]\right\}
$$

where $K$ is the slope factor and $V_{1 / 2}$ is the voltage at which there is half-maximal activation. This yielded a $V_{1 / 2}$ of $-19 \pm$ $1 \mathrm{mV}$ for L current compared with $-34 \pm 3 \mathrm{mV}$ for T current. These data are consistent with the idea that two components of inward current were present in rabbit urethral myocytes.

Voltage dependence of inactivation. To assess the voltage dependence of inactivation of both currents, we employed a standard double-pulse protocol. Figure $2 A$ shows a typical experiment in which a cell was held at conditioning potentials ranging from -110 to $0 \mathrm{mV}$ for $2 \mathrm{~s}$ before stepping to the test potential of $0 \mathrm{mV}$ for $500 \mathrm{~ms}$ to evoke the peak L current. Most inactivation of this current occurred over the potential range of -60 to $-30 \mathrm{mV}$. The inactivation data were fitted with a Boltzmann equation, described above, where $V_{1 / 2}$ is the voltage
Fig. 2. Voltage-dependent inactivation of $\mathrm{L}$ and $\mathrm{T}$ currents in human urethral smooth muscle cells. A: a typical family of currents obtained by stepping to $0 \mathrm{mV}$ for $200 \mathrm{~ms}$ after application of a series of 2-s conditioning potentials from -110 to $+10 \mathrm{mV}$. $B$ : summary data demonstrating the voltage dependence of inactivation $(\mathrm{O})$ and activation $(\bullet)$ curves of the $\mathrm{L}$ current. Continuous lines represent Boltzmann fits to the data. $C$ : a typical inactivation profile for $\mathrm{T}$ current obtained by stepping to $-40 \mathrm{mV}$ for $200 \mathrm{~ms}$ after application of a series of 2-s conditioning potentials from -110 to $+10 \mathrm{mV}$. $D$ : summary data demonstrating the voltage dependence of inactivation ( $\square$ ) and activation ( $\square$ ) curves of the $\mathrm{T}$ current. Continuous solid lines represent Boltzmann fits to the data; continuous shaded lines show the fits obtained for $\mathrm{L}$ current from the data in $B$ for comparison.
A
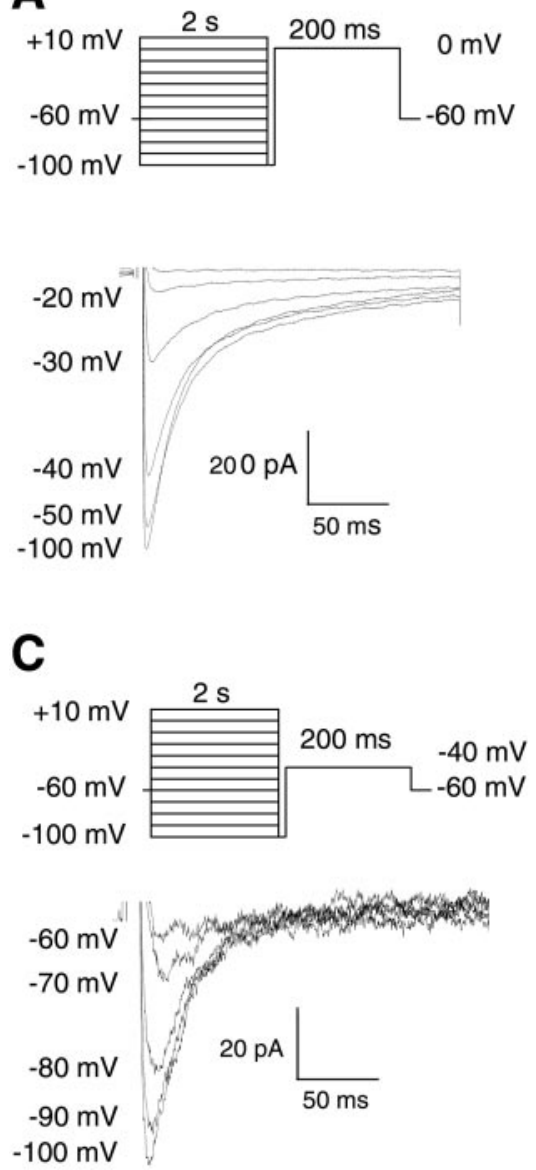

B

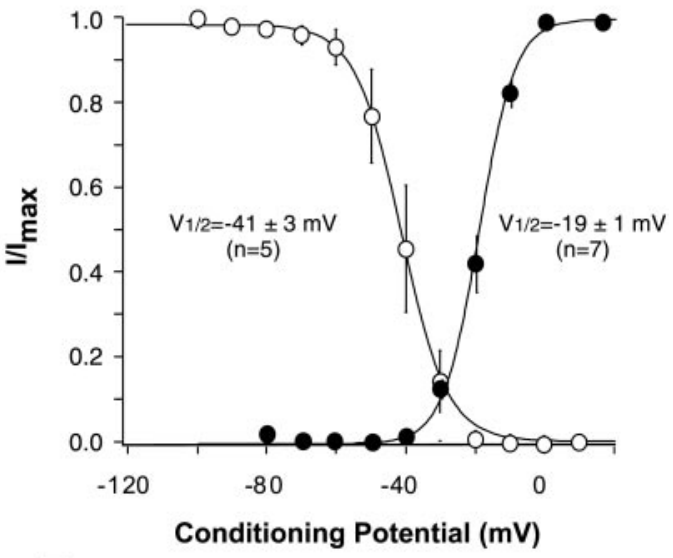

D

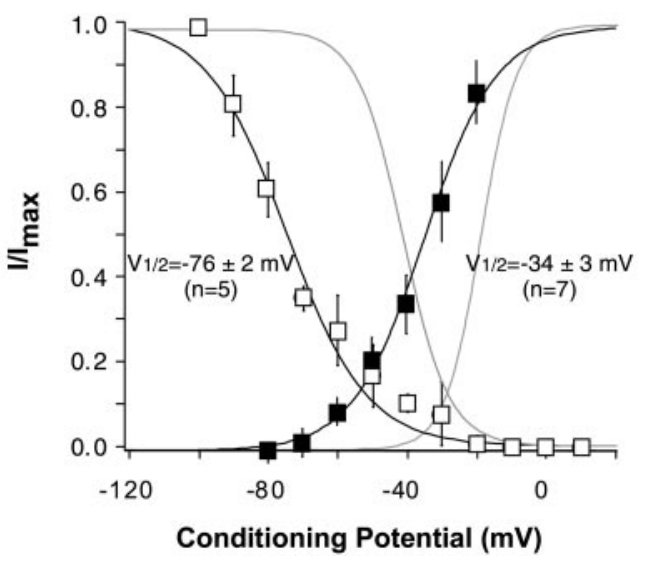


at which there is half-maximal inactivation. The $\mathrm{L}$ current inactivated with a $V_{1 / 2}$ of $-41 \pm 3 \mathrm{mV}$.

We next examined the inactivation of the $\mathrm{T}$ current by applying the same conditioning potentials as above but stepping to $-40 \mathrm{mV}$ to elicit $\mathrm{T}$ current with minimal activation of $\mathrm{L}$ current. Figure $2 C$ shows a typical example of voltagedependent inactivation obtained by using the protocol shown. In contrast to the $\mathrm{L}$ current, the $\mathrm{T}$ current was almost completely inactivated when conditioning potentials were more positive than $-40 \mathrm{mV}$. Figure $2 D$ shows summary data obtained from five cells. When these data were fitted with the Boltzmann equation, a $V_{1 / 2}$ of $-76 \pm 2 \mathrm{mV}$ was obtained (solid lines). The shaded lines in Fig. $2 D$ show the Boltzmann fits to the activation/inactivation curves for the $\mathrm{L}$ current for comparison.

Pharmacology of inward currents. Having demonstrated that two components of inward current could be isolated on the basis of their voltage dependence of activation and inactivation, we next wanted to test whether each of these currents possessed a different pharmacological profile. We first wanted to exclude the possibility that the negatively activating current was similar to the novel, $\mathrm{Ba}^{2+}$-sensitive, voltage-dependent cation current described previously (14). Figure $3 A$, inset, shows the protocol used to evoke both components of inward current. Cells were held at $-100 \mathrm{mV}$ and stepped to $-40 \mathrm{mV}$ for $250 \mathrm{~ms}$ to evoke T current and then depolarized to $-50 \mathrm{mV}$ for $500 \mathrm{~ms}$ to inactivate most of the remaining $\mathrm{T}$ current. The cell was further depolarized to $0 \mathrm{mV}$ for $250 \mathrm{~ms}$ to evoke peak L-type $\mathrm{Ca}^{2+}$ current. When $\mathrm{Ca}^{2+}$ was substituted with equimolar $(1.8 \mathrm{mM}) \mathrm{Ba}^{2+}$, the amplitude of the $\mathrm{T}$ current was increased slightly but the rate of inactivation was little affected. In contrast, the $\mathrm{L}$ current was increased in amplitude and its time-dependent inactivation was slowed. Figure $3, B$ and $C$, shows summary bar charts for six cells in which the amplitude and time constant $(\tau)$ of inactivation, respectively, of the T and $\mathrm{L}$ currents were recorded before and during substitution of external $\mathrm{Ca}^{2+}$ with equimolar $\mathrm{Ba}^{2+}$. Under control conditions, the $\mathrm{T}$ current recorded at $-40 \mathrm{mV}$ was $-37 \pm 10 \mathrm{pA}$, and this was significantly increased to $-59 \pm 16 \mathrm{pA}$ in the presence of $1.8 \mathrm{mM} \mathrm{Ba}^{2+}(P<0.05)$. Although the amplitude of the $\mathrm{T}$ current was enhanced by $\mathrm{Ba}^{2+}$, the time constant of inactivation was little affected $\left(\tau=19 \pm 2 \mathrm{~ms}\right.$ in $\mathrm{Ca}^{2+}$ compared with $16 \pm 2 \mathrm{~ms}$ in $\mathrm{Ba}^{2+}$; not significant). In contrast, the time constant of inactivation of the peak $\mathrm{L}$ current was increased from $24 \pm 3$ to $68 \pm 7 \mathrm{~ms}(P<0.05)$ in the presence of $\mathrm{Ba}^{2+}$, and the amplitude increased from $-265 \pm 69 \mathrm{pA}$ in $1.8 \mathrm{mM}$ $\mathrm{Ca}^{2+}$ to $-386 \pm 77 \mathrm{pA}$ in $1.8 \mathrm{mM} \mathrm{Ba}^{2+}(P<0.05)$.

Effect of nifedipine. We examined the effect of the L-type $\mathrm{Ca}^{2+}$ channel antagonist nifedipine on both components of inward current. Figure $4 A$, inset, shows the protocol used to evoke both $\mathrm{T}$ and $\mathrm{L}$ current. Figure $4 A$ shows currents obtained before and during application of increasing concentrations of nifedipine. Application of nifedipine at concentrations up to $300 \mathrm{nM}$ decreased the amplitude of the L current by 90\%, whereas the $\mathrm{T}$ current was only reduced by $\sim 10 \%$. The ability of nifedipine to discriminate between both components of inward current is reflected in the summary data shown in Fig. $4 B$. The concentration-effect curves illustrating the effects of nifedipine on $\mathrm{T}$ and $\mathrm{L}$ current were constructed from data

A
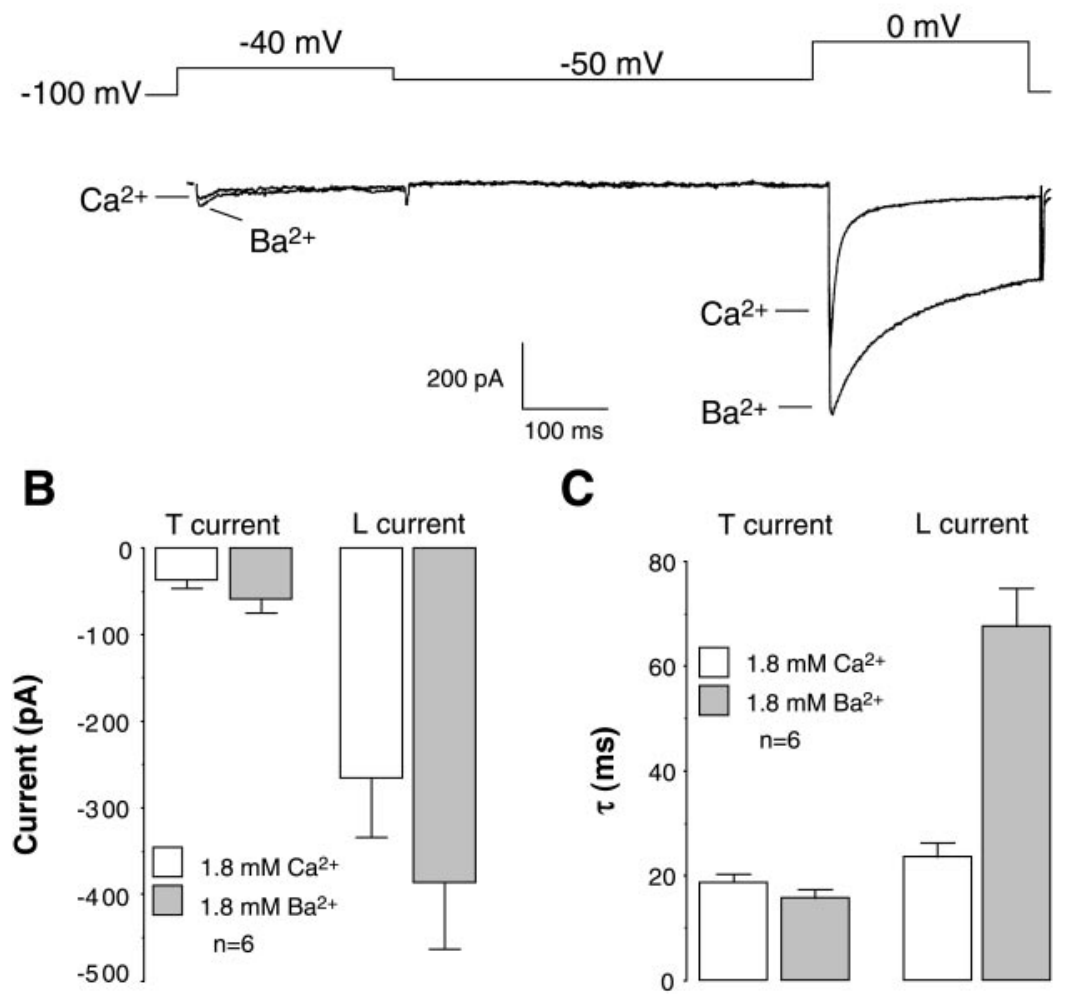

Fig. 3. Effects of $\mathrm{Ba}^{2+}$ on $\mathrm{T}$ and $\mathrm{L}$ currents. $A$ : peak $\mathrm{T}$ and $\mathrm{L}$ currents were evoked by a step from -100 to $-40 \mathrm{mV}$ for 250 $\mathrm{ms}$. A step to $-50 \mathrm{mV}$ for $500 \mathrm{~ms}$ was applied to inactivate T current, followed by a further step to $0 \mathrm{mV}$ to evoke peak $\mathrm{L}$ current in the same cell. Substitution of external $\mathrm{Ca}^{2+}$ with equimolar $\mathrm{Ba}^{2+}$ increased the amplitude and slowed the decay of the current evoked by a step from -50 to $0 \mathrm{mV}$ but had little effect on the amplitude of the current evoked by a depolarization to $-40 \mathrm{mV}$ from a holding potential of $-100 \mathrm{mV}$. $B$ : a summary bar graph for 6 cells in which the peak amplitude of the $\mathrm{T}$ and $\mathrm{L}$ current was plotted before (open bars) and during (filled bars) equimolar substitution of external $\mathrm{Ca}^{2+}$ with $\mathrm{Ba}^{2+}$. $C$ : a summary bar graph in which the time-dependent inactivation $(\tau)$ of the $\mathrm{T}$ and $\mathrm{L}$ currents was plotted before (open bars) and during (filled bars) equimolar substitution of external $\mathrm{Ca}^{2+}$ with $\mathrm{Ba}^{2+}$. 

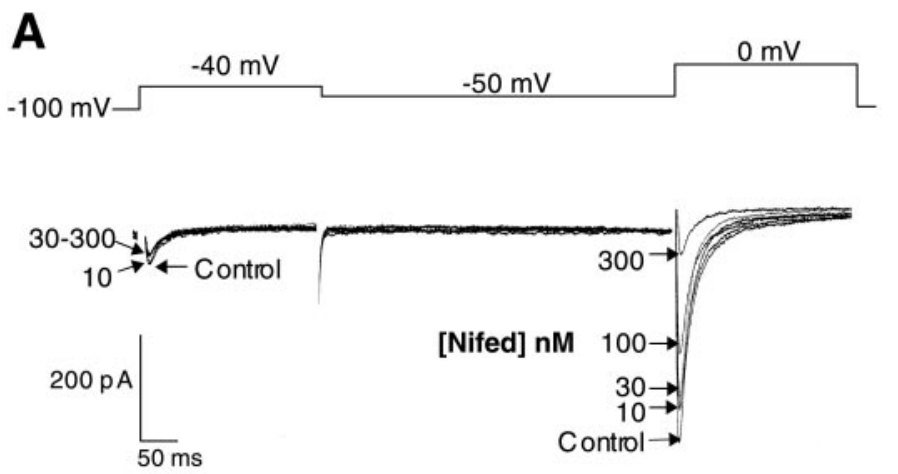

B

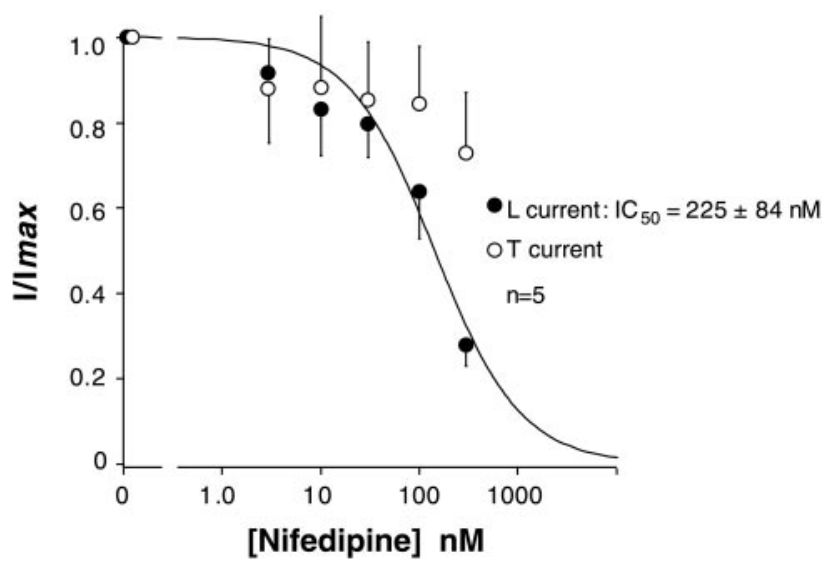

Fig. 4. Effect of nifedipine on $\mathrm{T}$ and $\mathrm{L}$ currents. $A$ : traces demonstrating the effect of increasing concentrations of nifedipine on the peak $\mathrm{T}$ and $\mathrm{L}$ current. Note that $300 \mathrm{nM}$ nifedipine practically abolished L current evoked by a step from -50 to $0 \mathrm{mV}$ but had less effect on the peak $\mathrm{T}$ current evoked by a step from -100 to $-40 \mathrm{mV}$. $B$ : a summary of effects of a variety of nifedipine concentrations on the peak $\mathrm{T}$ and $\mathrm{L}$ currents. Fitting the $\mathrm{L}$ current data with a Langmuir equation (continuous line; see text) yielded an $\mathrm{IC}_{50}$ of $225 \pm 84 \mathrm{nM}$. The $\mathrm{T}$ current data were not easily fitted with a Langmuir equation.

obtained from five cells. Fitting the data for the L current with a Langmuir equation of the form

$$
I_{\text {drug }} / I_{\text {control }}=1 /\left[1+\left([\text { drug }] / \mathrm{IC}_{50}\right)\right]
$$

where $\mathrm{IC}_{50}$ is the half-maximal effective dose, yielded an $\mathrm{IC}_{50}$ of $225 \pm 84 \mathrm{nM}$. In contrast, the data obtained from steps to $-40 \mathrm{mV}$ could not be easily fitted with a Langmuir equation. For example, whereas $3 \mathrm{nM}$ nifedipine reduced the $\mathrm{T}$ current by $\sim 10 \%$, the next three concentrations had little further effect. This reduction by $30 \mathrm{nM}$ nifedipine presumably reflects its effect on a small component of L current present at $-40 \mathrm{mV}$.

Effect of $\mathrm{Ni}^{2+}$. To test the possibility that the currents activated at negative potentials were carried through T-type $\mathrm{Ca}^{2+}$ channels, we next examined the effects of a variety of concentrations of $\mathrm{Ni}^{2+}$ on both components of current. Figure $5 A$, inset, shows the typical double-pulse protocol used to activate $\mathrm{T}$ and $\mathrm{L}$ current at -40 and $0 \mathrm{mV}$, respectively. Figure $5 A$ shows the effects of increasing concentrations of $\mathrm{Ni}^{2+}$ on both currents. Although $\mathrm{Ni}^{2+}$ reduced both currents in a concentration-dependent manner, the $\mathrm{T}$ current was more sensitive to $\mathrm{Ni}^{2+}$ and was reduced by $80 \%$ in the presence $30 \mu \mathrm{M}$ $\mathrm{Ni}^{2+}$. In contrast, the same concentration of $\mathrm{Ni}^{2+}$ only reduced the L current by $\sim 25 \%$. Figure $5 B$ shows summary concen- tration-effect curves for the effect of $\mathrm{Ni}^{2+}$ on $\mathrm{T}$ and $\mathrm{L}$ current in five cells. Fitting the data with the Langmuir equation yielded an $\mathrm{IC}_{50}$ for the $\mathrm{T}$ current of $7 \pm 2 \mu \mathrm{M}$ compared with $324 \pm 74 \mu \mathrm{M}$ for the L current.

Effect of mibefradil. We next assessed the effects of mibefradil on both currents to find a concentration that could selectively inhibit the $\mathrm{T}$ current. Figure $6 \mathrm{~A}$ shows the typical effects of 0.1 and $0.3 \mu \mathrm{M}$ mibefradil on $\mathrm{T}$ and $\mathrm{L}$ currents. Although $0.1 \mu \mathrm{M}$ mibefradil reduced the $\mathrm{T}$ current by $\sim 80 \%$, it had no effect on L current. Even when the concentration of mibefradil was increased to $0.3 \mu \mathrm{M}$, the L current was reduced by only $20 \%$ but the T current was abolished. Figure $6 B$ shows summary concentration-effect curves, which illustrate the selective blockade of $\mathrm{T}$ current by mibefradil at concentrations $<0.3 \mu \mathrm{M}$. Fitting the data for the L current with the Langmuir equation yielded an $\mathrm{IC}_{50}$ of $2.6 \pm 1.1 \mu \mathrm{M}$. Although the $\mathrm{T}$ current data could be fitted with a Langmuir to yield an $\mathrm{IC}_{50}$ of $\sim 40 \mathrm{nM}$, the absence of data at concentrations below 0.1 $\mu \mathrm{M}$ made it difficult to accurately determine the $\mathrm{IC}_{50}$. However, it is clear from these data that the $\mathrm{IC}_{50}$ for mibefradil of the $\mathrm{T}$ current is approximately three orders of magnitude less than that of the L current.

Having established that $0.1 \mu \mathrm{M}$ mibefradil could selectively block the $\mathrm{T}$ current at $-40 \mathrm{mV}$ without any effect on the $\mathrm{L}$ current, we examined its effects on the $I-V$ relationships from cells held at $-100 \mathrm{mV}$. Figure $7 A$ shows currents elicited by a series of depolarizing steps from $-70 \mathrm{mV}$ through to $0 \mathrm{mV}$ before (left) and during (middle) application of mibefradil. Figure $7 A$, right, shows the mibefradil-sensitive current, which activated at $-50 \mathrm{mV}$, inactivated rapidly, and peaked at -20 $\mathrm{mV}$. Figure $7 B$ shows a summary of six similar experiments in which the mean currents before and during mibefradil application are plotted. Difference currents were obtained by subtraction of the currents before and during mibefradil application. The mibefradil-sensitive current possessed characteristics typical of $\mathrm{T}$ current, because it activated at $-50 \mathrm{mV}$ and peaked at $-20 \mathrm{mV}$.

Intracellular recording. To assess the contributions of both currents to spontaneous electrical activity in the urethra, we examined the effects of $\mathrm{Ni}^{2+}$, mibefradil, and nifedipine on strips of rabbit urethra impaled with intracellular microelectrodes. The mean resting membrane potential was $-50 \pm 0.5$ $\mathrm{mV}$ ( $n=185$ cells from 86 animals), which was close to the peak $\mathrm{T}$ window current (see Fig. 2). We found considerable variation in the resting membrane potential and type of electrical activity recorded between successive impalements, even in the same tissue. These observations are consistent with the idea that the urethra possesses a heterogeneous population of cells that may contribute to electrical activity (24). The first type of activity that was observed in $\sim 16 \%$ of impalements consisted of single rapid spikes that were followed by large afterhyperpolarizations. The second type of activity was observed in $\sim 10 \%$ of impalements and consisted of slow waves similar to those recorded by Hashitani et al. (9). In $\sim 74 \%$ of impalements, we observed spontaneous activity that consisted of spike complexes and is illustrated in Figs. 8 and 9. These complexes were composed of a series of spikes superimposed on a spontaneous depolarization (SD). The complexes occurred at a mean frequency of $5 \pm 0.4 \mathrm{~min}^{-1}\left(\right.$ range: $\left.2-12 \mathrm{~min}^{-1}\right)$ and had on average $5 \pm 0.3$ spikes per complex (range: $2-16$ spikes 
A
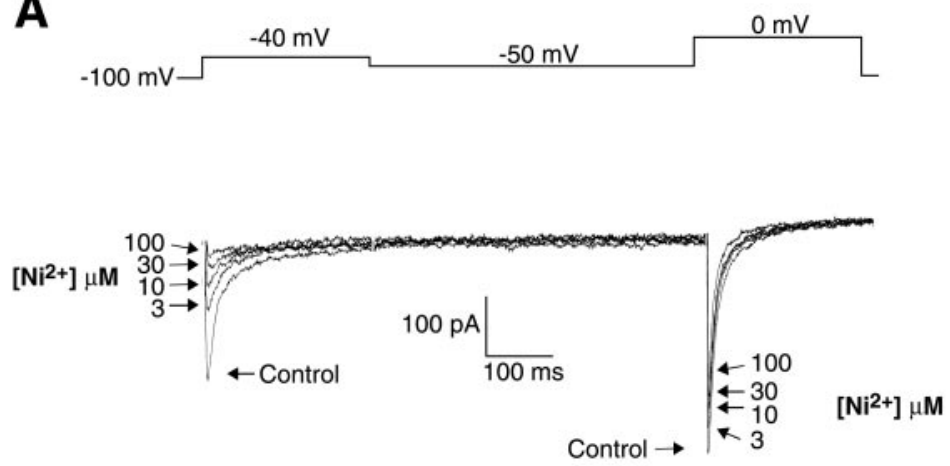

B

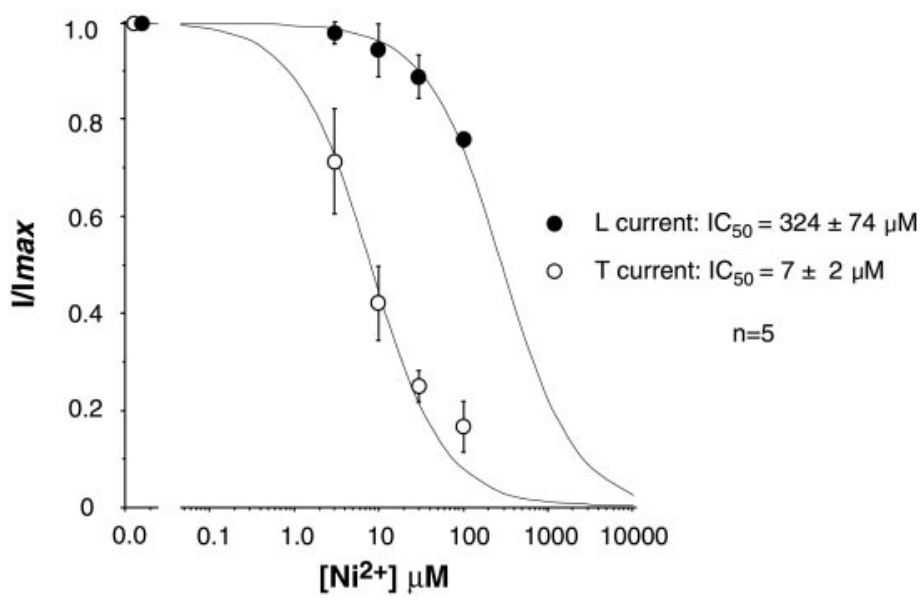

Fig. 5. Effects of $\mathrm{Ni}^{2+}$ on $\mathrm{T}$ and $\mathrm{L}$ currents. $A$ : peak $\mathrm{T}$ and $\mathrm{L}$ currents were evoked using the protocol described in Fig. $3 A$. Application of $10 \mu \mathrm{M} \mathrm{Ni}^{2+}$ reduced the amplitude of the T current by $\sim 60 \%$ but reduced the L current by only $15 \%$. $B$ : summary concentration-effect curves obtained from 5 cells. Fitting the data obtained for $\mathrm{T}$ and $\mathrm{L}$ current with the Langmuir equation (continuous lines) yielded $\mathrm{IC}_{50}$ values of $7 \pm 2$ and $324 \pm 74 \mu \mathrm{M}$, respectively. per complex). The mean amplitude of the SD observed in spike complexes was $10 \pm 0.5 \mathrm{mV}$ (range: 3-27 mV), and the duration of the complex was $2.1 \pm 0.1 \mathrm{~s}$ (range: $0.1-7.4 \mathrm{~s}$ ). Cells that showed this type of activity had a mean resting membrane potential of $-51 \pm 0.6 \mathrm{mV}(n=137$; range: -34 to $-70 \mathrm{mV}$ ). Because the majority of impalements demonstrated the latter type of activity, we concentrated our efforts on examining the effects of $\mathrm{L}$ and $\mathrm{T}$ channel blockers on cells that showed spike complex activity. To quantify the effects of drugs on this activity, we measured four parameters: the number of SDs, the number of spikes during each SD, the maximum amplitude of the spikes, and the resting membrane potential.

Effect of $\mathrm{Ni}^{2+}$ on spontaneous activity. Figure 8, $A$ and $B$, shows typical examples of the effects of $\mathrm{Ni}^{2+}$ on spontaneous activity. In these examples the SD fired at a frequency of 3 $\min ^{-1}$. Application of $30 \mu \mathrm{M} \mathrm{Ni}^{2+}$ (Fig. 8B) decreased the frequency of SD to $\sim 2 \mathrm{~min}^{-1}$ but failed to affect either resting membrane potential, the amplitude of the spikes within the complex, or the number of spikes per SD (compare Fig. 8, A and $B$, insets). Figure $8, C-E$, summarizes SD frequency, spike amplitude, and the number of spikes per SD recorded in eight cells before and during application of $30 \mu \mathrm{M} \mathrm{Ni}^{2+}$. These data confirm that neither spike amplitude nor the number of spikes per SD were significantly altered. Although application of $\mathrm{Ni}^{2+}$ had no effect on resting membrane potential $(-54 \pm 2$ $\mathrm{mV}$ before compared with $-54 \pm 2 \mathrm{mV}$ during $\mathrm{Ni}^{2+}$ ), the SD frequency was significantly reduced from $5.2 \pm 1.4$ to $3.6 \pm$ $0.8 \min ^{-1}(P<0.05)$.
Effect of mibefradil on spontaneous activity. Having demonstrated that $100 \mathrm{nM}$ mibefradil could selectively block $\mathrm{T}$ current, we examined its effects on SDs. Figure 9A shows a recording of spontaneous activity before application of mibefradil. Figure 9A, inset, shows a typical SD on an expanded time scale. In this example, SDs occurred at a frequency of 5 $\min ^{-1}$. In the presence of mibefradil (Fig. 9B), the frequency of SDs was reduced to $3 \mathrm{~min}^{-1}$, but there was no significant change in spike amplitude, resting membrane potential, or the number of spikes per SD (compare Fig. 9, $A$ and $B$, insets). Figure $9, C-E$, summarizes the mean frequency of SDs, spike amplitude, and number of spikes per SD in six cells before and during application of $100 \mathrm{nM}$ mibefradil. Although the frequency of SDs was significantly reduced from $3.8 \pm 0.8$ to $2.8 \pm 1 \mathrm{~min}^{-1}(P<0.05)$, none of the other parameters was significantly altered. Similarly, resting membrane potential was unchanged by mibefradil $(-53 \pm 1 \mathrm{mV}$ before compared with $-52 \pm 1 \mathrm{mV}$ during mibefradil).

Effect of nifedipine on spontaneous activity. To assess the contribution of L current to spontaneous electrical activity, we examined the effects of $100 \mathrm{nM}$ nifedipine on spike complexes. Even though this concentration would only be expected to block $\sim 40 \%$ of the L current, it was chosen because it should have little effect on $\mathrm{T}$ current (see Fig. 4). In contrast to the effects of $\mathrm{T}$ current blockade, application of nifedipine had no significant effect on the frequency of SDs $\left(7.4 \pm 1.7 \mathrm{~min}^{-1}\right.$ before compared with $7.0 \pm 2 \mathrm{~min}^{-1}$ during nifedipine, $n=8$ ). However, application of nifedipine significantly reduced both the amplitude and frequency of the spikes. In eight experiments 
A
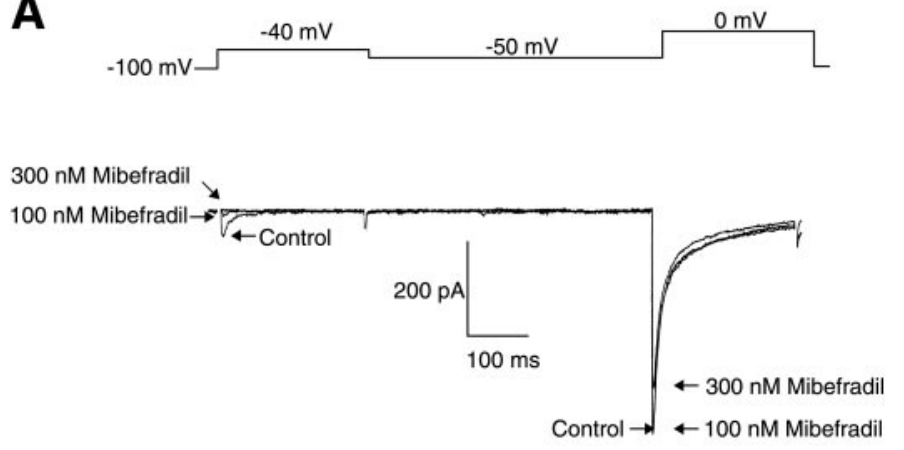

B

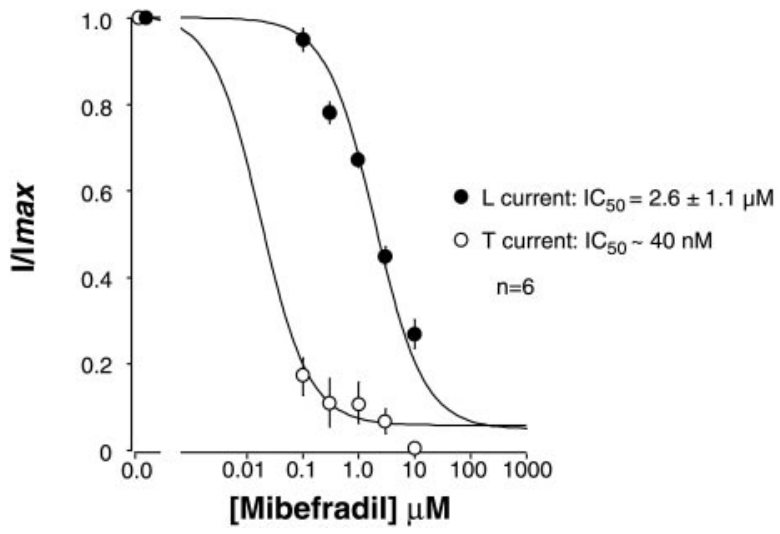

Fig. 6. Effects of mibefradil on $\mathrm{T}$ and $\mathrm{L}$ currents. A: peak $\mathrm{T}$ and $\mathrm{L}$ currents were evoked using the protocol described in Fig. 3A. Application of $100 \mathrm{nM}$ mibefradil reduced the amplitude of the $\mathrm{T}$ current by $\sim 75 \%$ but had no measurable effect on the $\mathrm{L}$ current. When the concentration of mibefradil was increased to $300 \mathrm{nM}$, the T current was abolished but the L current was reduced by only $20 \%$. B: summary concentration-effect curves obtained from 6 cells. Fitting the data obtained for T and $\mathrm{L}$ current with the Langmuir equation (continuous lines) yielded $\mathrm{IC}_{50}$ values of $\sim 40 \mathrm{nM}$ and $2.6 \pm 1.1 \mu \mathrm{M}$, respectively.

the amplitude of the spikes was reduced from $44 \pm 4 \mathrm{mV}$ before to $16 \pm 6 \mathrm{mV}(P<0.05)$ during application of nifedipine, and the number of spikes per SD was reduced from $4.2 \pm 1$ to $0.7 \pm 0.3$ spikes per complex during nifedipine $(P<0.05)$.

\section{DISCUSSION}

The results of this study demonstrate the presence of two components of $\mathrm{Ca}^{2+}$ current with characteristics typical of $\mathrm{T}$ and $L$ currents found in a variety of lower urinary tract smooth muscles, including human bladder, guinea pig bladder, and human urethra $(5,10,27)$. Perez-Reyes (22) has recently provided a review on $\mathrm{T}$ currents and demonstrated that they, like the currents described in the present study, could be readily discriminated from $\mathrm{L}$ currents on the basis of their activation at relatively low voltages (between -80 and -60 $\mathrm{mV})$, inactivation over negative voltage ranges $\left(V_{1 / 2}\right.$ between -90 and $-70 \mathrm{mV}$ ), equal permeability to $\mathrm{Ca}^{2+}$ and $\mathrm{Ba}^{2+}$, relative insensitivity to dihydropyridines, and sensitivity to mibefradil and $\mathrm{Ni}^{2+}$.

The electrophysiological characteristics of both $\mathrm{T}$ and $\mathrm{L}$ currents in rabbit urethra were remarkably similar to those found in the human urethra (10). Thus the T currents in both cell types could be evoked at potentials positive to $-70 \mathrm{mV}$ and inactivated with a $V_{1 / 2}$ of $-76 \mathrm{mV}$ (rabbit) compared with $-80 \mathrm{mV}$ (human urethral myocytes; Ref. 10). In both rabbit and human myocytes, the $\mathrm{L}$ currents activated at $\sim-40 \mathrm{mV}$, inactivated more slowly than the T currents, and had a $V_{1 / 2}$ of inactivation of -41 and $-45 \mathrm{mV}$, respectively. Similarly, the reversal potential of the $\mathrm{T}$ current in both cell types was $\sim 20$ $\mathrm{mV}$, whereas the $\mathrm{L}$ currents reversed at $\sim 45 \mathrm{mV}$. Differences between $\mathrm{T}$ and $\mathrm{L}$ current reversal potentials have been noted in other studies (26) and are presumably due to the fact that $\mathrm{T}$ channels pass significant outward currents at potentials positive to $+20 \mathrm{mV}$ in the presence of normal external $\mathrm{Ca}^{2+}(8)$.

It is interesting to note that although the sensitivity of the $\mathrm{L}$ currents to nifedipine in rabbit and human urethra myocytes was similar ( $\mathrm{IC}_{50}$ of 159 and $225 \mathrm{nM}$, respectively), there was a significant difference in sensitivity to $\mathrm{Ni}^{2+}$. The $\mathrm{L}$ current in human urethral myocytes was approximately fivefold more sensitive to $\mathrm{Ni}^{2+}\left[\mathrm{IC}_{50}=65 \mathrm{nM}\right.$ (10) compared with $\mathrm{IC}_{50}=$ $324 \mathrm{nM}$ in rabbit]. These data suggest that there may be subtle differences in the molecular species encoding the L channels in both cell types, although this would require confirmation.

Although both human and rabbit urethral myocytes possess $\mathrm{T}$ current, some studies have failed to demonstrate $\mathrm{T}$ current in smooth muscle cells isolated from the urethra of different species (28). Whether this reflects species variation or perhaps differences in recording conditions is unclear at present. However, it is interesting to note that $\mathrm{T}$ current amplitude is significantly influenced by temperature (20-22). In the present study we found that reducing the bath temperature from 35 to $\sim 22^{\circ} \mathrm{C}$ practically abolished the $\mathrm{T}$ current evoked by a step from -100 to $-40 \mathrm{mV}$ and reduced the $\mathrm{L}$ current evoked from a holding potential of -50 to $0 \mathrm{mV}$ by $\sim 50 \%(n=3$; data not shown). Given the temperature sensitivity of the T current, it is essential that studies are carried out at body temperature before the presence of $\mathrm{T}$ current can be excluded.

Substitution of external $\mathrm{Ca}^{2+}$ with $\mathrm{Ba}^{2+}$ greatly enhanced the amplitude and slowed the inactivation of the current evoked by a step from -50 to $0 \mathrm{mV}$. Interestingly, the amplitude of the current evoked by a step from -100 to $-40 \mathrm{mV}$ was also increased in $\mathrm{Ba}^{2+}$, unlike the novel, voltage-dependent, nonselective cation current demonstrated in murine colonic myocytes (14). This effect on T current could be due to contaminating $\mathrm{L}$ current; however, because the time constant of inactivation of the T current was little affected, this seems unlikely. These data suggest that $\mathrm{Ba}^{2+}$ may permeate $\mathrm{T}$ channels in urethral myocytes more easily than $\mathrm{Ca}^{2+}$, as has been demonstrated in both native T channels (12) and reexpressed $\alpha_{1 \mathrm{H}^{-}}$ subunits (18).

The sensitivity of the rabbit urethral $\mathrm{T}$ current to $\mathrm{Ni}^{2+}\left(\mathrm{IC}_{50}\right.$ $\sim 7 \mu \mathrm{M}$ ) was also similar to that described in human urethral myocytes (10). The low concentration of $\mathrm{Ni}^{2+}$ required to block the $\mathrm{T}$ currents in urethral myocytes suggests that the pore-forming subunit in these myocytes may be $\alpha 1_{\mathrm{H}}$, because these have been shown to be $\sim 10$-fold more sensitive to $\mathrm{Ni}^{2+}$ than the $\alpha_{1 G^{-}}$and $\alpha_{1 I^{-}}$subunits recently cloned $(13,17)$. We also examined the effects of the $\mathrm{T}$ channel blocker mibefradil (19) and found that it could dramatically reduce the T current at concentrations as low as $100 \mathrm{nM}$ while having little effect on L current. Although we did not use low enough concentrations of mibefradil to produce a full concentration-effect curve for its effects on $\mathrm{T}$ current, it is clear from the data presented that the 
A

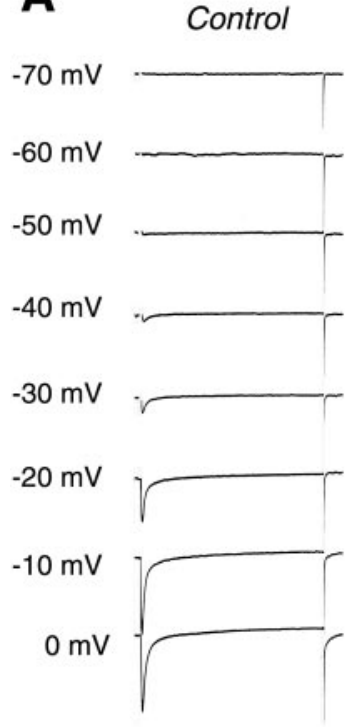

Mibefradil
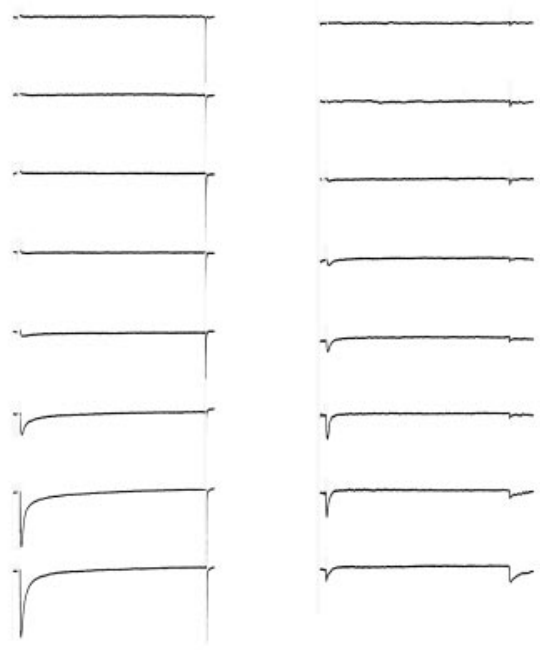

\section{Difference}

B

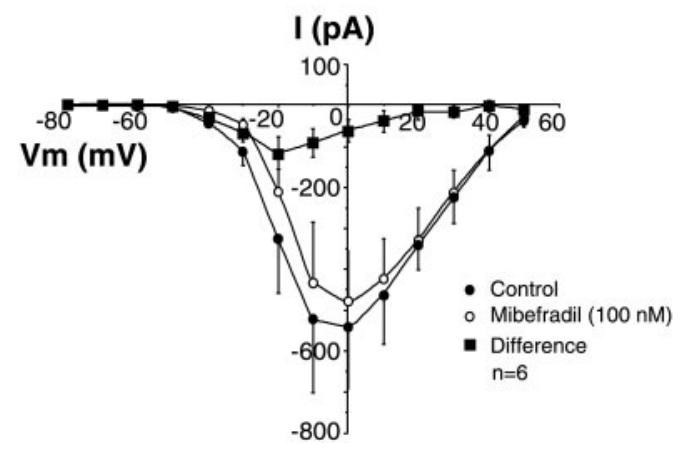

Fig. 7. Application of $100 \mathrm{nM}$ mibefradil blocks $\mathrm{T}$ current selectively. A: currents obtained by depolarizing from $-70 \mathrm{mV}$ through to $0 \mathrm{mV}$ from a holding potential of $-100 \mathrm{mV}$ under control conditions (left) and during application of mibefradil (middle). Mibefradil-sensitive current (right) was obtained by subtraction. $B$ : a summary $I-V_{\mathrm{m}}$ plot for 6 cells obtained before (control) and during application of $100 \mathrm{nM}$ mibefradil. Mibefradil-sensitive (difference) current was obtained by subtraction. This difference current activated at approximately -50 $\mathrm{mV}$ and peaked at $-20 \mathrm{mV}$, whereas the mibefradilresistant current activated at approximately -40 $\mathrm{mV}$ and peaked at $0 \mathrm{mV}$.
$\mathrm{IC}_{50}$ is $<100 \mathrm{nM}$, which is in agreement with that reported for $\mathrm{T}$ channels recorded in $\mathrm{Ca}^{2+}$-containing solutions (22).

The pattern of electrical activity recorded with intracellular microelectrodes from the whole rabbit urethra was complex, consisting of three main patterns of phasic activity: spike activity, slow waves, and spike complexes. The heterogeneity of electrical activity observed in the present study was not unexpected given that recordings were made from the whole urethra, which consists of circular and longitudinal smooth muscle layers in which both interstitial cells of Cajal (ICC) and smooth muscle cells are present. At present we do not know whether the different types of activity observed reflect different properties or populations of cells within the smooth muscle layers. However, given the similarities between the electrical activity recorded with intracellular electrodes and that observed in isolated urethral cells, it is tempting to speculate that the slow waves, spikes, and spike complexes represent recordings from distinct cell populations. The first type of activity resembled the single fast spikes recorded from strips of urethra previously (4) and were similar to the single action potentials that can be evoked from rabbit urethral myocytes with brief depolarizations (24). The slow wave activity recorded in the minority of impalements bore a striking resemblance to the spontaneous activity observed in isolated rabbit urethra ICC under current clamp (24) and to the intracellular recordings from circular muscle by Hashitani et al. (9). This suggests that slow wave activity is from urethral ICC or cells that are well coupled to these. The third type of activity, which was recorded in $\sim 74 \%$ of impalements from the urethra, resembled neither the rapid fast spikes nor the slow waves recorded from isolated smooth muscle cells and ICC, respectively. These spike complexes comprised a series of rapid action potentials, superimposed on a SD. We believe that this type of activity represents the electrical activity recorded from "follower" smooth muscle cells that are located "downstream" to the pacemaker cells, as is the case in the gastrointestinal tract $(6,7)$. However, until we can confirm that the different patterns of electrical activity represent recordings from different populations of cells within the urethra, these ideas remain speculative. Future experiments must be directed toward repeating the elegant experiments of Dickens et al. (7) on the urethra, to address these issues.

The range of membrane potentials recorded by using intracellular microelectrodes was also quite variable (from -34 to $-70 \mathrm{mV}$ ) even in different impalements of the same tissue. It is unlikely that any $\mathrm{T}$ current would be available in cells that had membrane potentials of $-34 \mathrm{mV}$, but, as Fig. $2 D$ suggests, significant $\mathrm{T}$ current would be available at more hyperpolarized membrane potentials. Given that the peak of the $\mathrm{T}$ window current was close to the mean resting membrane potential recorded with intracellular microelectrodes (approximately 
A

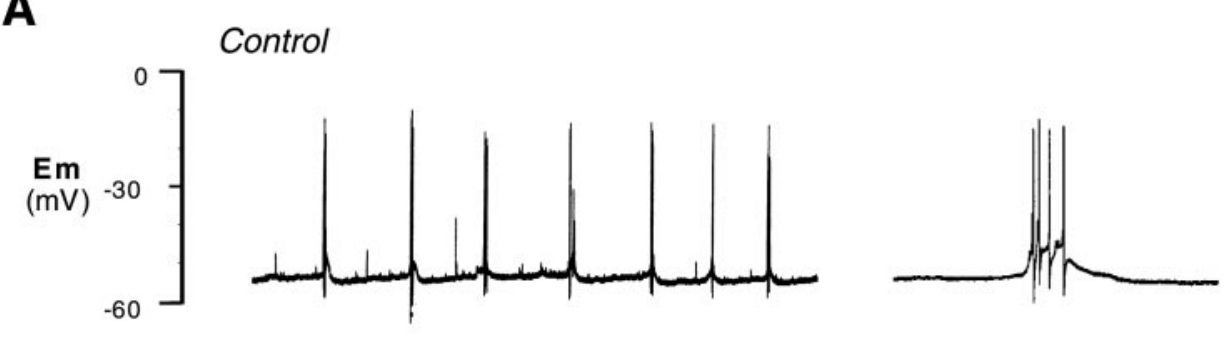

B

Fig. 8. Nickel slows spontaneous depolarization (SD) frequency. A: an example of spontaneous electrical activity recorded from the urethra. Inset: a single complex on an expanded time scale. The complexes consisted of an SD upon which a number of spikes were superimposed. $B$ : the reduction in frequency of $\mathrm{SD}$ in the presence of $\mathrm{Ni}^{2+}(30 \mu \mathrm{M})$. As the inset suggests, $\mathrm{Ni}^{2+}$ application had no effect on the number of spikes during the SD. Bar graphs summarize 8 experiments in which the effects of $\mathrm{Ni}^{2+}$ were assessed on SD frequency $(C)$, the peak amplitude of the spikes $(D)$, and the number of spikes per SD $(E) . * P<0.05$ vs. control.

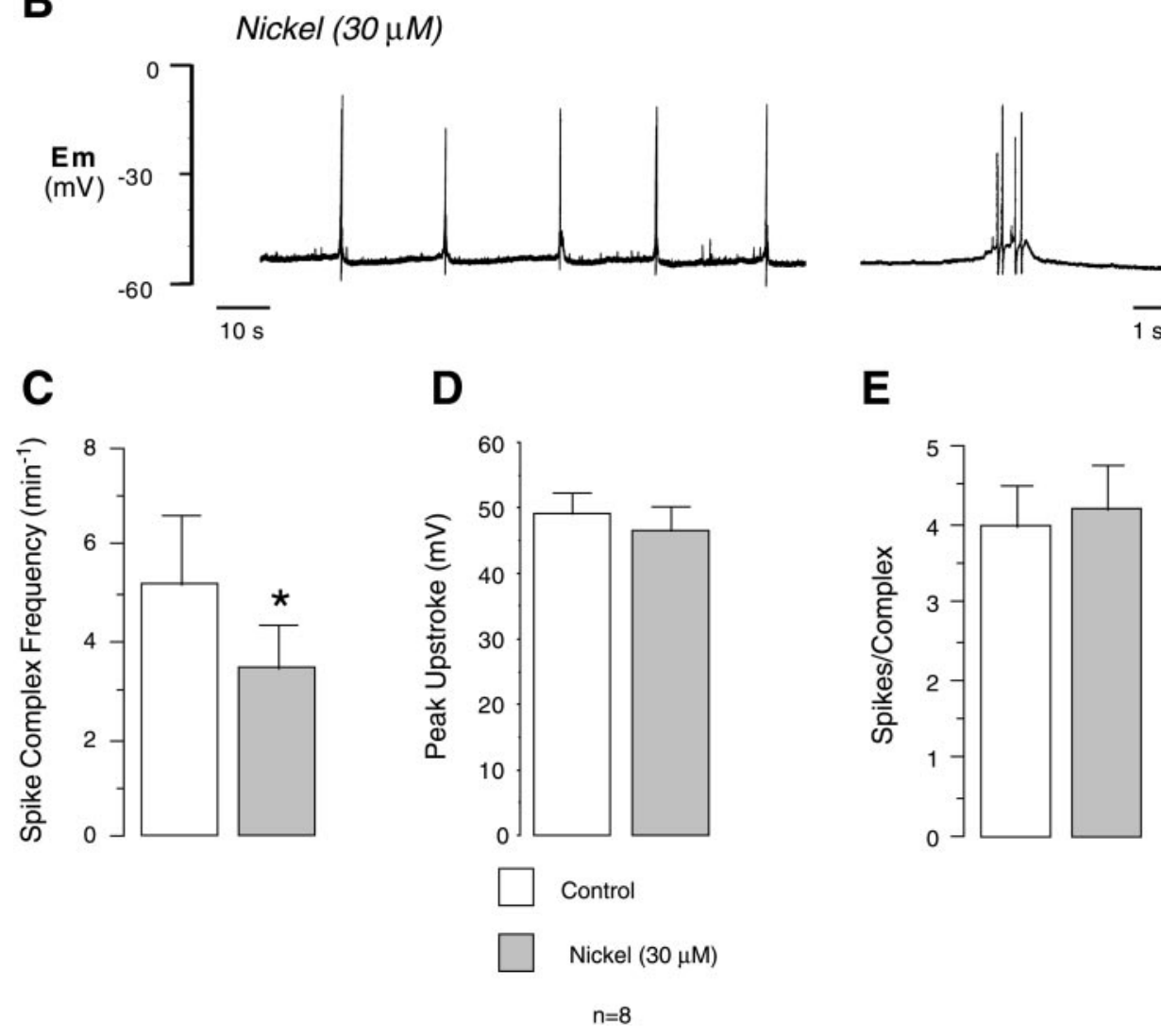

Nickel $(30 \mu \mathrm{M})$

$-50 \mathrm{mV}$ ), it is possible that sufficient $\mathrm{T}$ current would be present to contribute to electrical activity.

The ability of both mibefradil and $\mathrm{Ni}^{2+}$ to alter spontaneous activity in strips of urethra suggests that sufficient $\mathrm{T}$ current was available to contribute to electrical activity even at membrane potentials of approximately $-50 \mathrm{mV}$. When we selectively blocked the $\mathrm{T}$ current, it was clear that neither the amplitude of the spikes nor the number of spikes per SD were altered. However, both drugs significantly reduced the frequency of SDs. These data suggest that the $\mathrm{T}$ current in the urethra contributes to the modulation of SD frequency but contributes little to spike generation. However, we cannot discount the possibility that these effects are due to blockade of ionic conductances other than $\mathrm{T}$ current, because mibefradil has been shown to block $\mathrm{K}^{+}, \mathrm{Na}^{+}$, and $\mathrm{Cl}^{-}$channels (22). However, the concentrations of $\mathrm{Ni}^{2+}$ and mibefradil used in the present study are thought to be relatively specific for $\mathrm{T}$ current (22).

Another alternative explanation is that mibefradil and $\mathrm{Ni}^{2+}$ mediate their effects by altering the pacemaking mechanisms

in urethral interstitial cells. However, one might expect that if the pacemaker mechanism depended on $\mathrm{T}$ current, then urethral interstitial cell slow wave frequency should show some voltage dependence. However, as Sergeant et al. (23) demonstrated, the frequency of slow waves in urethral interstitial cells was little affected by voltage. Another possible explanation of our results is that the $\mathrm{T}$ current may contribute to the propagation of the pacemaking depolarizations throughout the urethra. A number of studies on the gastrointestinal tract have demonstrated that conductances with properties similar to $\mathrm{T}$ currents are present in ICC (16) and that these currents contribute to the propagation of the pacemaking signal throughout the bulk smooth muscle via the ICC (29). At present, we cannot exclude the possibility that urethral interstitial cells express $\mathrm{T}$ currents or that they are essential for the propagation of the pacemaking depolarizations in the urethra. However, the presence of $T$ current in urethral smooth muscle suggests that it could facilitate the propagation of the pacemaking depolarizations. Given that the T current activates at negative membrane potentials, relatively small depolarizations (presumably sup- 
A

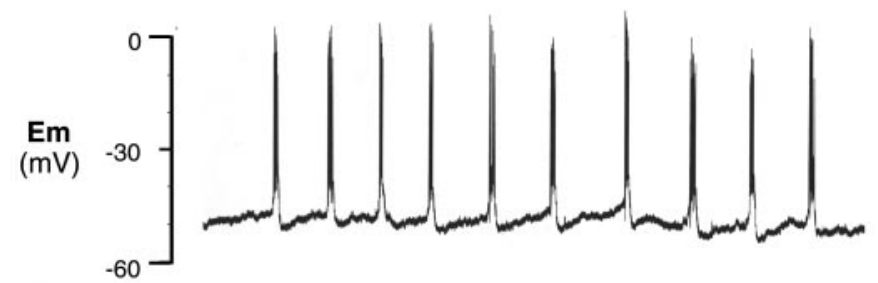

B

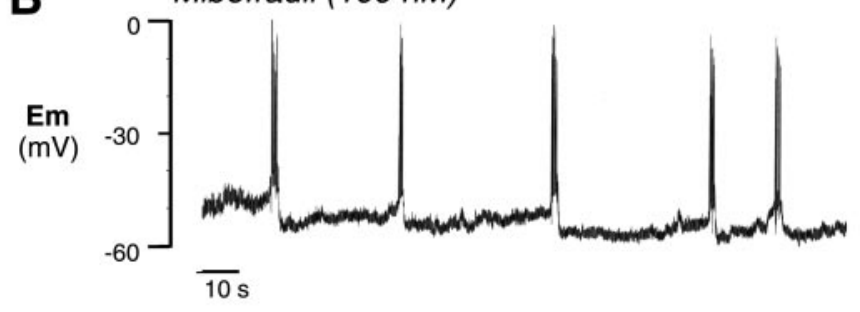

C

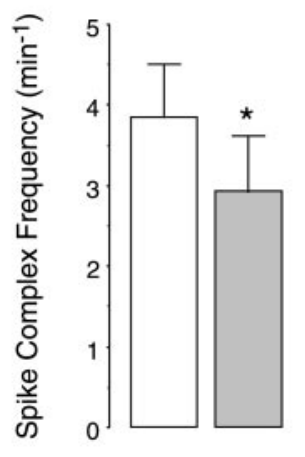

D

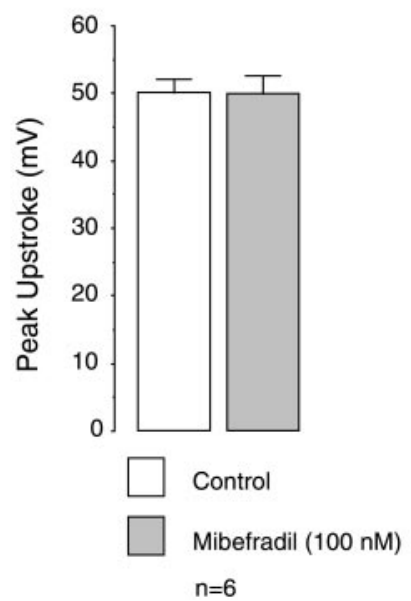

plied by urethral interstitial cells) would be required to elevate the membrane potential sufficiently to activate $\mathrm{T}$ currents, bring the membrane potential into the threshold range for $\mathrm{L}$ current activation, and thus set off a series of spike complexes. Such a mechanism could contribute to the modulation of the electrical activity in the urethra and thus alter tone.

\section{ACKNOWLEDGMENTS}

We thank Action Medical Research, the Wellcome Trust, and the Ralph Shackman Trust for funding this study.

\section{REFERENCES}

1. Brading AF. The physiology of the mammalian outflow tract. Exp Physiol 84: 1737-1743, 1999.

2. Bradley JE, Anderson UA, Woolsey SM, McHale NG, Thornbury KD, and Hollywood MA. Characterisation of T type calcium current and its role in spontaneous activity in rabbit urethral smooth muscle (Abstract). J Physiol 548P: P70, 2003.

3. Bridgewater M, MacNeil HF, and Brading AF. Regulation of tone in pig urethral smooth muscle. J Urol 150: 223-228, 1993.

4. Callahan SM and Creed KE. The effects of oestrogens on spontaneous activity and responses to phenylephrine of the mammalian urethra. J Physiol 358: 35-46, 1985.
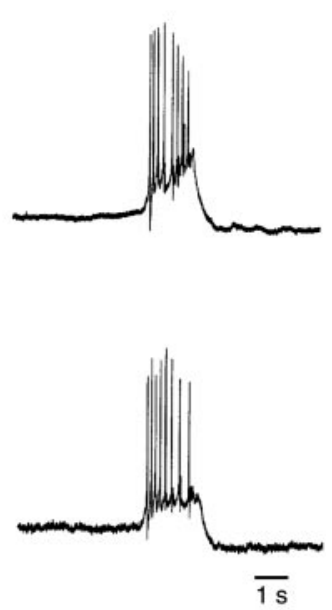

E

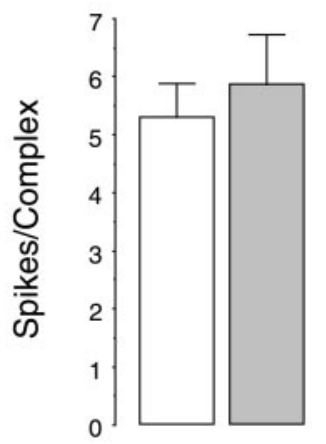

Fig. 9. Selective blockade of $T$ current with mibefradil reduces SD frequency. A: typical SD activity recorded from the urethra in the absence of drugs. Inset: a typical complex recorded on an expanded time scale. $B$ : the reduction in frequency of SD in the presence of mibefradil $(100 \mathrm{nM})$. Inset demonstrates the lack of effect of mibefradil on the spikes. Bar graphs summarize 6 experiments in which the effects of mibefradil were assessed on SD frequency $(C)$, the peak amplitude of the spikes $(D)$, and the number of spikes per SD (E).
5. Chow KY, Wu C, Sui GP, and Fry CH. Role of the T-type $\mathrm{Ca}^{2+}$ current on the contractile performance of guinea pig detrusor smooth muscle. Neurourol Urodyn 22: 77-82, 2003.

6. Cousins HM, Edwards FR, Hickey H, Hill CE, and Hirst GDS. Electrical coupling between the myenteric interstitial cells of Cajal and adjacent muscle layers in the guinea-pig gastric antrum. $J$ Physiol 550: 829-844, 2003.

7. Dickens EJ, Hirst GD, and Tomita T. Identification of rhythmically active cells in guinea-pig stomach. J Physiol 514: 515-531, 1999.

8. Fukushima $\mathbf{Y}$ and Hagiwara $\mathbf{S}$. Currents carried by monovalent cations through calcium channels in mouse neoplastic B lymphocytes. $J$ Physiol 358: 255-284, 1985.

9. Hashitani H, Van Helden DF, and Suzuki H. Properties of spontaneous depolarizations in circular smooth muscle cells of rabbit urethra. $\mathrm{BrJ}$ Pharmacol 118: 1627-1632, 1996.

10. Hollywood MA, Woolsey S, Walsh IK, Keane PF, McHale NG, and Thornbury KD. T- and L-type $\mathrm{Ca}^{2+}$ currents in freshly dispersed smooth muscle cells from the human proximal urethra. J Physiol 550: 753-764, 2003.

11. Horn R and Marty A. Muscarinic activation of ionic currents measured by a new whole-cell recording method. J Gen Physiol 92: 145-159, 1988.

12. Huguenard JR and Prince DA. A novel T-type current underlies prolonged $\mathrm{Ca}^{2+}$-dependent burst firing in GABA-ergic neurons of rat thalamic reticular nucleus. J Neurosci 12: 3804-3817, 1992.

13. Klockner U, Lee JH, Cribbs LL, Daud A, Hescheler J, Pereverzev A, Perez-Reyes E, and Schneider T. Comparison of the $\mathrm{Ca}^{2+}$ currents 
induced by expression of three cloned $\alpha_{1}$ subunits, $\alpha_{1 \mathrm{G}}, \alpha_{1 \mathrm{H}}$ and $\alpha_{1 \mathrm{I}}$, of low-voltage-activated T-type $\mathrm{Ca}^{2+}$ channels. Eur J Neurosci 11:41714178, 1999.

14. Koh SD, Monaghan K, Ro S, Mason HS, Kenyon JL, and Sanders KM. Novel voltage-dependent non-selective cation conductance in murine colonic myocytes. J Physiol 533: 341-355, 2001.

15. Kotlikoff MI, Herrera G, and Nelson MT. Calcium permeant ion channels in smooth muscle. Rev Physiol Biochem Pharmacol 134:147199, 1999.

16. Lee HK and Sanders KM. Comparison of ionic currents from interstitial cells and smooth muscle cells of canine colon. $J$ Physiol 460: 135-152, 1993.

17. Lee JH, Gomora JC, Cribbs LL, and Perez-Reyes E. Nickel block of three cloned T-type calcium channels: low concentrations selectively block $\alpha_{1 \mathrm{H} .}$ Biophys J 77: 3034-3042, 1999.

18. McRory JE, Santi CM, Hamming KS, Mezeyova J, Sutton KG, Baillie DL, Stea A, and Snutch TP. Molecular and functional characterization of a family of rat brain T-type calcium channels. J Biol Chem 276: 39994011, 2001.

19. Mishra SK and Hermsmeyer K. Selective inhibition of T-type $\mathrm{Ca}^{2+}$ channels by Ro 40-5967. Circ Res 75: 144-148, 1994.

20. Narahashi T, Tsunoo A, and Yoshii M. Characterization of two types of calcium channels in mouse neuroblastoma cells. J Physiol 383: 231-349, 1987.

21. Nobile M, Carbone E, Lux HD, and Zucker H. Temperature sensitivity of $\mathrm{Ca}$ currents in chick sensory neurones. Pflügers Arch 415: 658-663, 1990.
22. Perez-Reyes E. Molecular physiology of low-voltage-activated T-type calcium channels. Physiol Rev 83: 117-161, 2003.

23. Sergeant GP, Hollywood MA, McCloskey KD, McHale NG, and Thornbury KD. Role of $\mathrm{IP}_{3}$ in modulation of spontaneous activity in pacemaker cells of rabbit urethra. Am J Physiol Cell Physiol 280: C1349C1356, 2001.

24. Sergeant GP, Hollywood MA, McCloskey KD, Thornbury KD, and McHale NG. Specialised pacemaking cells in the rabbit urethra. $J$ Physiol 526: 359-366, 2000.

25. Shafei M, Thornbury KD, McHale NG, and Hollywood MA. Relative contributions of calcium influx and calcium stores to myogenic tone in the rat urethra (Abstract). J Physiol 548P: O15, 2003.

26. Staes M, Talavera K, Klugbauer N, Prenen J, Lacinova L, Droogmans G, Hofmann F, and Nilius B. The amino side of the C-terminus determines fast inactivation of the T-type calcium channel $\alpha_{1 \mathrm{G}}$. J Physiol 530: 35-45, 2001.

27. Sui GP, Wu C, and Fry CH. Inward calcium currents in cultured and freshly isolated detrusor muscle cells: evidence of a T-type calcium current. J Urol 165: 621-626, 2001.

28. Teramoto N, Yunoki T, Ikawa S, Takano N, Tanaka K, Seki N, Naito $\mathrm{S}$, and Ito $\mathrm{Y}$. The involvement of L-type $\mathrm{Ca}^{2+}$ channels in the relaxant effects of the ATP-sensitive $\mathrm{K}^{+}$channel opener ZD6169 on pig urethral smooth muscle. Br J Pharmacol 134: 1505-1515, 2001.

29. Ward SM, Baker SA, de Faoite A, and Sanders KM. Propagation of slow waves requires $\mathrm{IP}_{3}$ receptors and mitochondrial $\mathrm{Ca}^{2+}$ uptake in canine colonic muscles. J Physiol 549: 207-218, 2003.

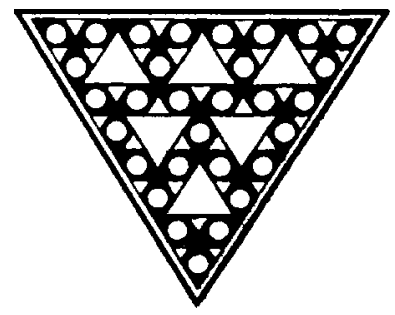

